\title{
Perlindungan Biokakisan Keluli Karbon Akibat Bakteria Penurun Sulfat yang Dipencil daripada Minyak Mentah Tropika
}

(Biocorrosion Protection of Carbon Steel due to Isolated Sulfate-Reducing Bacteria from Tropical Crude Oil)

\author{
MOHD NAZRI IDRIS*, ABDUl RAZAK DAUD, NURAKMA MAHAT, FATHUL KARIM SAHRANI
}

\& NORINSAN KAMIL OTHMAN

\begin{abstract}
Ancaman biokakisan akibat aktiviti bakteria penurun sulfat (SRB) pada saluran paip keluli karbon dalam industri petroleum boleh menjejaskan kelancaran aliran pengangkutan minyak mentah dan meningkatkan kos pengoperasian. Usaha bagi melindungi keluli karbon serta pengawalan SRB masih memerlukan kajian yang berterusan. Dalam kajian ini, keberkesanan tetrametilamonium bromida (TMB), karboksimetil trimetilamonium (BTN) dan benzalkonium klorida (BKC) bagi melindungi keluli karbon di dalam persekitaran yang mengandungi SRB diuji melalui kaedah pengutuban elektrokimia dinamik (PED) dan morfologi keluli karbon dianalisis menggunakan mikroskop elektron imbasan. Analisis PED mendapati penggunaan TMB, BTN dan BKC masing-masing berupaya mengurangkan kadar kakisan sehingga 0.13, 0.56 dan $0.17 \mathrm{~mm} / \mathrm{thn}$ berbanding $8.91 \mathrm{~mm} / \mathrm{thn}$ pada larutan kawalan yang mengandungi SRB. Morfologi permukaan biofilem mengesahkan kadar pertumbuhan SRB serta hasilan metabolisme bakteria ini turut mengalami penyusutan. Kajian ini menunjukkan dua mekanisme kawalan kakisan didapati berlaku iaitu mekanisme perencatan kakisan melalui penjerapan sebatian amonium kuaterner pada permukaan keluli karbon serta berlakunya proses tindak balas mitigasi sebatian ini dengan bakteria SRB. Kesimpulannya, TMB, BTN dan BKC didapati berupaya melindungi keluli karbon daripada mengalami kakisan akibat aktiviti SRB.
\end{abstract}

ABSTRAK

Kata kunci: Bakteria penurun sulfat; biokakisan; keluli karbon

\section{ABSTRACT}

Biocorrosion menace of carbon steel pipeline in petroleum industry attributed to sulfate-reducing bacteria (SRB) activity is disrupting the crude oil transportation process and increase the operational cost. Efforts for protecting the carbon steel pipeline and controlling the SRB activities are continuously being researched. In this work, the effectiveness of tetramethylammonium bromide (TMB), carboxymethyl trimethylammonium (BTN) and benzalkonium chloride (BKC) for protecting carbon steel in environment containing SRB was studied by potential dynamic polarization (PED) method and the morphology of carbon steel surface was analyzed by scanning electron microscope. PED indicated that TMB, BTN and $B K C$ were capable of reducing the corrosion rate to $0.13,0.56$ and $0.17 \mathrm{~mm} / \mathrm{yr}$, respectively, as compared with 8.91 $\mathrm{mm} / \mathrm{yr}$ of control medium, which contained SRB. The morphology of surface biofilm proven that the rate of SRB growth and their metabolism product has also been reduced. This study suggested that there are two mechanisms of corrosion protection i.e. the present quaternary ammonium compounds inhibited the corrosion process on account of adsorption mechanism, meanwhile the mitigation process of SRB and their activities occurred due to interaction process between the quaternary ammonium compounds and SRB itself. In conclusion, TMB, BTN and BKC are able to protect the carbon steel from actively corroding due to SRB activities.

Keywords: Biocorrosion; carbon steel; sulfate-reducing bacteria

\section{PENGENALAN}

Proses pemindahan minyak mentah kerap dilakukan melalui sistem saluran paip keluli yang terdedah kepada pelbagai persekitaran, termasuk laluan di bawah tanah dan air laut. Keadaan ini telah mengundang pelbagai masalah kakisan pada kedua-dua permukaan luaran dan dalaman paip (Al-Jaroudi et al. 2011). Untuk itu, langkah pengurusan dan pengawalan kakisan dengan menggunakan kaedah seperti saduran cat, perlindungan katodik dan perencat kakisan telah digunakan. Namun kehadiran perbagai mikrobial yang menyebabkan kakisan dalam minyak mentah terutamanya SRB telah meningkatkan lagi tahap kemusnahan bahagian dalaman paip keluli (Abdullah et al. 2014; Stipaničev et al. 2013). Keadaan ini disebabkan aktiviti semula jadi SRB yang berupaya menghasilkan ion sulfida daripada tindak balas penurunan sulfat dan lainlain ikatan sulfur seperti sulfit dan tiosulfat. Tindak balas ion-ion sulfida dengan ion hidrogen terlarut menyebabkan pembentukan sebatian berasid $\mathrm{H}_{2} \mathrm{~S}$ yang berbahaya dan toksik. Kehadiran $\mathrm{H}_{2} \mathrm{~S}$ bukan sahaja meningkatkan kadar kakisan keluli, malah turut menurunkan kualiti minyak mentah melalui proses pemasaman serta pemendakan 
pepejal tidak terlarut dalam saluran paip keluli dan akhirnya mengundang kepada masalah yang lebih besar seperti penutupan dan pemberhentian aktiviti loji, kebocoran, pencemaran, letupan dan peningkatan kos penyelenggaraan (Fink 2013).

Untuk itu, pengurusan dan kawalan terhadap penglibatan SRB amat perlu dititik berat bagi menjamin mutu dan perjalanan operasi minyak mentah yang baik. Penggunaan bahan perencat dan biosid adalah antara langkah-langkah yang telah diguna pakai bagi penyelesaian masalah ini. Bahan perencat lebih tertumpu kepada perlindungan permukaan dalaman keluli, manakala biosid digunakan bagi mengawal aktiviti SRB dan pembentukan biofilem. Glutaraldehid dan nitrit adalah antara biosid yang telah lama digunakan bagi mengatasi pembentukan biofilem SRB (Davidova et al. 2001; Gardner \& Stewart 2002). Sebahagian penggunaan biosid oleh Industri Minyak dan Petrokimia disenaraikan dalam kajian literatur Yemashova et al. (2007). Penambahan sesetengah bahan kimia sebagai sinergi kepada biosid komersial turut mendapat perhatian pelbagai pihak. Antaranya adalah penggunaan biosid hijau etilenadiamina disuksinat telah digunakan bagi meningkatkan keupayaan glutaraldehid bagi rawatan biofilem SRB (Wen et al. 2009). Xu et al. (2011a) dalam kajian mereka telah cuba memperkenalkan penggunaan asid D-amino dengan beberapa campuran seperti D-tirosin, D-metionin, D-triptofan dan D-leusin sebagai penambahbaikan kepada biosid komersial iaitu tetrakis (hidroksimetil)fosfonium sulfat dan asid etilenediamin-N,N'-disuksinik. Sebahagian formulasi terhadap biosid komersial ini didapati berupaya mengawal pembentukan biofilem D. vulgaris. Selain larutan biosid, penggunaan kombinasi sterina dan $\mathrm{N}$-vinil-2-pirolidon dalam logam nano-komposit turut didapati memberikan kecekapan perencatan yang tinggi kepada SRB apabila digunakan sebagai saduran kepada keluli karbon (Fathy et al. 2013). Namun sehingga kini penggunaan bahan biosid bagi mengawal bakteria SRB dan penggunaan bahan perencat kakisan masih melibatkan penggunaan bahan kimia yang berlainan. Pemilihan dan penggunaan bahan kimia yang sama serta berupaya bertindak sebagai kedua-dua fungsi berkenaan masih belum dipelopori sepenuhnya. Usaha bagi mendapatkan bahan kimia yang mampu bertindak dengan baik terhadap pengawalan aktiviti mikrobial dan tidak memudaratkan pengguna serta alam sekitar juga masih giat diusahakan.

Antara bahan kimia yang berkesan mengatasi permasalan SRB adalah sebatian amonium kuaterner. Sebatian ini berupaya meningkatkan keberkesanan biosid untuk tempoh yang lebih pantas. Ini dibuktikan melalui penggunaan sebatian kationik $19 \mathrm{~N}^{\mathrm{TM}}$ dengan natrium hipoklorida atau glutaraldehid (Fink 2013). Selain itu, sebatian amonium kuaterner turut mempunyai aktiviti spektrum yang lebih luas, agen permukaan (surfaktan) yang baik, tahap pengekalan yang baik dan memiliki tindak balas kimia yang lemah dengan bahan kimia lain (Boivin 1995). Dalam kajian ini, keberkesanan sebatian amonium kuaterner tetrametilamonium bromida (TMB),
Karboksimetil trimetilamonium (BTN) dan benzalkonium klorida (BKC) telah dikaji terhadap konsortium SRB yang diperoleh daripada minyak mentah beriklim tropika. Pemilihan TMB, BTN dan BKC yang mempunyai struktur molekul pendek dan bersifat hidrofilik/hidrofobik yang baik, serta kewujudan sifat toksik bagi ketiga-tiga bahan berkenaan, dijangkakan berupaya menjerap dengan baik pada permukaan keluli dan berupaya bertindak sebagai biosid terhadap bakteria SRB bagi membunuh serta menyekat perkembangan metabolisme bakteria SRB berkenaan. Kaedah pengutuban elektrokimia dinamik (PED) digunakan bagi menentukan kadar kakisan pada keluli karbon akibat aktiviti SRB dan keberkesanan semua sebatian amonium kuaterner disahkan menggunakan mikroskop elektron imbasan.

Objektif utama kajian adalah untuk menentukan kesan aktiviti konsortium SRB yang diperoleh daripada minyak mentah tropika terhadap keluli karbon. Seterusnya adalah untuk menentukan tahap keberkesanan sebatian TMB, BTN dan BKC dalam mengawal aktiviti konsortium SRB menggunakan medium VMNI iaitu medium bagi pembiakan SRB. Berdasarkan keputusan PED, ketiga-tiga sebatian TMB, BTN dan BKC didapati berupaya menurunkan kadar kakisan kepada $0.13,0.56$ dan $0.17 \mathrm{~mm} /$ thn berbanding 8.91 $\mathrm{mm} /$ thn larutan kawalan yang mengandungi konsortium SRB masing-masing pada tempoh inkubasi 7 hari. Perlindungan biokakisan keluli karbon didapati berlaku melalui mekanisme penjerapan dan juga perencatan sel iaitu melalui proses interaksi elektrostatik antara SRB dan sebatian amonium kuaterner.

\section{BAHAN DAN KAEDAH}

Komposisi kimia keluli karbon API 5L yang digunakan dalam kajian ini terdiri daripada $0.26 \%$ bt. C, $0.47 \%$ bt. Mn, $0.01 \%$ bt. S, $0.01 \%$ bt. P, $0.04 \%$ bt. Cr, $0.43 \%$ bt Si, $0.02 \%$ bt. Ni, $0.02 \%$ bt. Cu dan $0.13 \%$ bt. Al dan bakinya adalah Fe. Paip keluli ini dipotong kepada saiz kupon $10 \times 10 \times 5 \mathrm{~mm}$. Kupon kemudiannya dicanai dengan menggunakan kertas emeri dari grit 240 hingga 1200. Pada setiap peringkat canaian, kupon dibasuh dengan air suling dan dibilas dengan aseton. Kupon kemudiannya disambung dengan wayar kuprum menggunakan pateri stanum sebelum dibenam dalam epoksi resin bagi menutup seluruh permukaan kecuali permukaan kerja.

Sebatian amonium kuaterner TMB, BTN dan BKC diperoleh dari Sigma Aldrich Sdn. Bhd. Manakala larutan VMNI disediakan seperti tatacara kajian Mahat et al. (2015). Sampel korsortium SRB diperoleh dari Makmal Biologi Universiti Kebangsaan Malaysia. SRB ini telah dipencilkan daripada minyak mentah tropika yang diperoleh dari luar persisir Malaysia. Sebanyak $5 \mathrm{~mL}$ daripada stok konsortium SRB dimasukkan ke dalam medium VMNI menggunakan $28 \mathrm{~mL}$ botol universal dan diinkubasi dalam inkubator selama 3 hari pada suhu $30^{\circ} \mathrm{C}$. Kemudiannya, larutan ini diempar pada kitaran $3500 \mathrm{rpm}$ selama 5 min sebelum diasingkan daripada larutan ampaian. Mendakan 
yang diperoleh ini digunakan sebagai kelompok SRB bagi semua kajian berikutnya.

Bagi kajian kakisan keluli karbon menggunakan medium VMNI tanpa dan dengan kehadiran konsortium SRB, sampel disediakan dengan menggunakan botol bertutup $100 \mathrm{~mL}$. Sampel kelompok SRB dimasukkan semula ke dalam larutan VMNI yang baru. Semua larutan berserta elektrod kerja keluli karbon diinkubasi semula dalam inkubator pada suhu $30^{\circ} \mathrm{C}$ untuk tempoh 3 hingga 15 hari. Manakala kajian terhadap keberkesanan amonium kuaterner dijalankan dengan memasukkan sebatian TMB, BTN dan BKC pada kepekatan 512, 1024, 2048 dan 4096 ppm masing-masing ke dalam larutan VMNI yang mengandungi konsortium SRB dengan menggunakan botol $100 \mathrm{~mL}$. Untuk kajian biosid ini, semua sampel dimasukkan semula ke dalam inkubator selama 7 hari pada suhu $30^{\circ} \mathrm{C}$.

Kajian PED dijalankan dengan menggunakan potentiostat model Gamry PC4/750. Kajian dijalankan dengan menggunakan sel konvensional tiga elektrod. Rod platinum dan elektrod kalomel tepu telah digunakan masing-masing sebagai elektrod pembilang dan rujukan, manakala keluli karbon sebagai elektrod kerja. Semua elektrod dibiarkan mencapai keseimbangan pada keupayaan litar terbuka (OCP) selama 20 min sebelum arus dikenakan. Julat keupayaan telah ditentukan bermula daripada -250 sehingga $+250 \mathrm{mV}$ berdasarkan nilai OCP. Kadar imbasan keupayaan ditetapkan pada $1.0 \mathrm{mV} / \mathrm{s}$. Ketumpatan keluli karbon serta keseimbangan jisim molar masing-masing adalah $7.56 \mathrm{~g} / \mathrm{cm}^{3}$ dan $28.01 \mathrm{~g} / \mathrm{mol}$.

Kajian morfologi terhadap biofilem pada permukaan keluli karbon turut dijalankan menggunakan mikroskop elektron imbasan model Zeiss Supra 35VP. Sampel kupon kajian telah disediakan di dalam medium yang sama seperti penyediaan kajian PED. Selepas 7 hari inkubasi pada suhu $30^{\circ} \mathrm{C}$, semua kupon dikeluarkan dan direndam di dalam air suling selama 2 s sebelum dikeringkan dengan udara biasa. Analisis morfologi dijalankan tanpa sebarang pemercikan.

\section{KEPUTUSAN DAN PERBINCANGAN}

Fenomena biokakisan pada keluli karbon akibat aktiviti SRB daripada minyak mentah tropika telah dinilai melalui ujian PED menggunakan analisis penentuluaran kecerunan Tafel. Rajah 1 dan 2 masing-masing menunjukkan plot PED keluli karbon tanpa dan dengan kehadiran SRB untuk tempoh inkubasi 3 hingga 15 hari. Data analisis kadar kakisan daripada kedua-dua rajah berkenaan ditunjukkan pada Rajah 3. Keputusan kajian mendapati kehadiran SRB telah menyebabkan berlakunya peningkatan yang amat ketara pada kadar kakisan keluli karbon berbanding sampel yang sama di dalam larutan VMNI tanpa kehadiran SRB. Peningkatan kadar kakisan didapati maksimum pada tempoh inkubasi 7 hari dengan nilai $8.91 \mathrm{~mm} / \mathrm{thn}$. Nilai ini didapati menyusut untuk tempoh inkubasi 9 dan 15 hari. Berbanding kehadiran SRB, nilai kadar kakisan didapati jauh lebih rendah pada larutan kawalan VMNI. Namun sedikit peningkatan pada nilai kadar kakisan didapati berlaku iaitu daripada 0.24 kepada $0.71 \mathrm{~mm} /$ thn masingmasing bagi tempoh inkubasi 3 hari kepada 15 hari.

Keputusan ini membuktikan bahawa berlakunya pertambahan dalam kepekatan $\mathrm{H}_{2} \mathrm{~S}$ daripada aktiviti metabolisme semula jadi SRB. Rajah 3 turut membuktikan bahawa SRB berkembang dan tumbuh secara eksponen di dalam medium VMNI akibat kehadiran sumber nutrien sehingga kepada tahap maksimum pada hari ke-7. Aktiviti metabolisme ini telah menyebabkan berlakunya penurunan sebatian sulfat daripada medium VMNI kepada ion sulfida oleh SRB melalui proses respirasi bakteria berkenaan. Selanjutnya, ion sulfida bertindak balas dengan ion hidrogen terlarut dalam medium berkenaan bagi membentuk sebatian berasid $\mathrm{H}_{2} \mathrm{~S}$ yang bertindak sebagai agen pemasaman dan kakisan pada keluli karbon. Penurunan kadar kakisan selepas hari ke-7 memperlihatkan bahawa kandungan nutrien telah sempurna digunakan dan sebilangan besar daripada SRB mengalami kematian. Keadaan ini menyebabkan aktiviti metabolisme juga turut terencat. Keadaan yang sama didapati berlaku pada penggunaan SRB D. desulfuricans (Langumier et al. 2009; Xu et al. 2011b) dan D. vulgaris (Abdullah et al. 2014).

Peningkatan kadar kakisan keluli karbon dalam persekitaran VMNI tanpa SRB dengan peningkatan tempoh inkubasi didapati berpunca daripada tempoh dedahan permukaan keluli karbon yang lebih lama

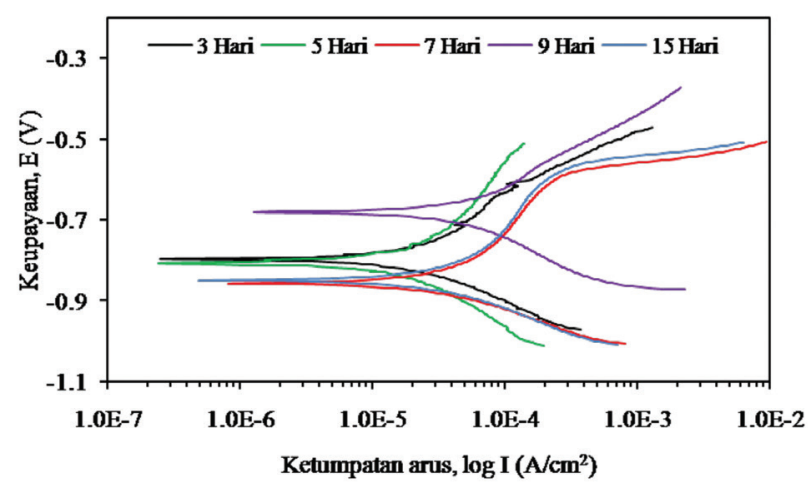

RAJAH 1. Plot PED bagi keluli karbon tanpa kehadiran SRB dan amonium kuaterner

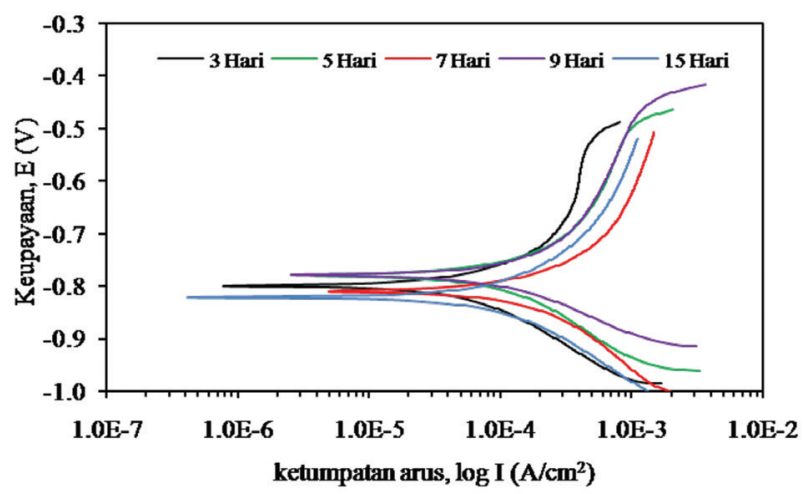

RAJAH 2. Plot PED bagi keluli karbon dengan kehadiran SRB dan tanpa amonium kuaterner 


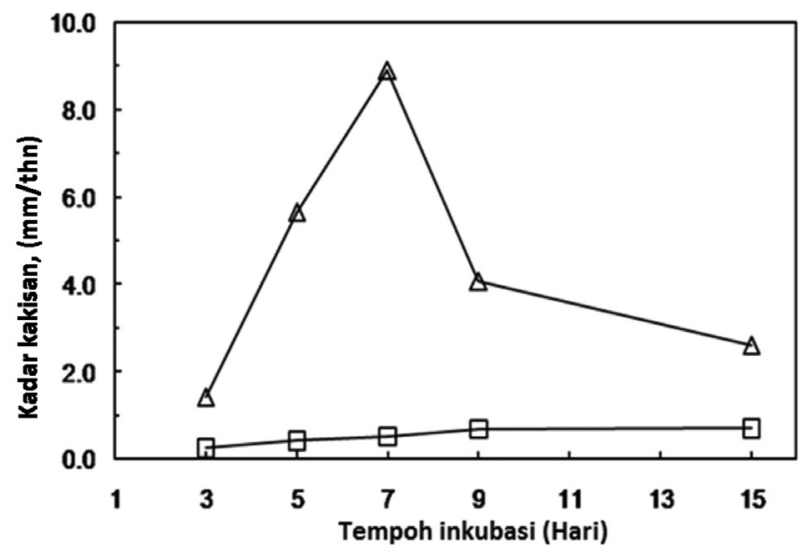

RAJAH 3. Kadar kakisan keluli karbon dalam medium VMNI ( $\square$ ) tanpa dan $(\Delta)$ dengan kehadiran SRB

dalam persekitaran VMNI dan menyebabkan berlakunya peningkatan tapak-tapak aktif permukaan anod pada keluli karbon. Namun keadaan ini masih jauh lebih rendah berbanding persekitaran VMNI yang mengandungi $\mathrm{H}_{2} \mathrm{~S}$. Untuk itu, penggunaan biosid bagi mengawal aktiviti SRB perlu dijalankan bagi mengawal proses biokakisan pada permukaan keluli karbon.

Ujian keberkesanan biosid menggunakan TMB, BTN dan BKC turut dijalankan menggunakan kaedah PED pada nilai kepekatan 512, 1024, 2048 dan 4096 ppm. Kepekatan ini digunakan berdasarkan kaedah pelarutan dwigandaan. Ujian ini dijalankan dalam tempoh maksimum penghasilan $\mathrm{H}_{2} \mathrm{~S}$ iaitu 7 hari inkubasi pada suhu $30^{\circ} \mathrm{C}$. Rajah 4 hingga 6 menunjukkan keputusan ujian PED terhadap keluli karbon dengan kehadiran SRB masing-masing bagi TMB, BTN dan BKC. Plot data kadar kakisan daripada analisis penentuluaran kecerunan Tafel ditunjukkan pada Rajah 7. Keseluruhan analisis mendapati dengan penggunaan TMB, BTN dan BKC, kadar kakisan menyusut pada semua kepekatan yang digunakan berbanding larutan kawalan SRB tanpa biosid iaitu $8.91 \mathrm{~mm} /$ thn (Rajah 3).

Keputusan menunjukkan penggunaan TMB mengalami penurunan tertinggi diikuti BKC dan BTN. Bagi TMB, nilai kadar kakisan berkurang dengan peningkatan kepekatan daripada $500 \mathrm{ppm}$ iaitu $0.30 \mathrm{~mm} /$ thn kepada $0.13 \mathrm{~mm} / \mathrm{thn}$ pada penggunaan kepekatan 2048 ppm. Nilai ini didapati sedikit meningkat dengan penggunaan kepekatan 4096 ppm iaitu $0.18 \mathrm{~mm} /$ thn. Penurunan kadar kakisan juga didapati berlaku pada penggunaan BKC dan BTN masingmasing daripada 500 ppm kepada 1024 ppm bagi BKC dan 2048 ppm bagi BTN. Nilai penurunan maksimum yang diperoleh bagi BKC dan BTN masing-masing adalah 0.17 dan $0.56 \mathrm{~mm} / \mathrm{thn}$. Bagi kedua-dua biosid BKC dan BTN, peningkatan kepekatan berikutnya telah meningkatkan semula kadar kakisan keluli di dalam persekitaran VMNI yang mengandungi SRB.

Penurunan kadar kakisan ini berlaku disebabkan peningkatan molekul amonium kuaterner yang berupaya menghalang tindak balas aktif spesies kakisan iaitu $\mathrm{H}_{2} \mathrm{~S}$ daripada bertindak balas dengan permukaan keluli karbon.
Peningkatan jumlah molekul menyebabkan keupayaan penjerapan molekul pada permukaan keluli bertambah dan membentuk lapisan filem nipis bagi menghalang pelarutan ion logam ke dalam medium (Rusling 1997). Pembentukan filem nipis menjadi sawar kepada pengaliran cas pada antara muka medium dan keluli yang menyebabkan penurunan dalam kadar aliran ketumpatan arus. Walau bagaimanapun, penjerapan molekul amonium kuaterner ini didapati berlaku sehingga tahap pelitupan permukaan maksimum dicapai. Selepas tahap ini, penambahan molekul berikutnya boleh menyebabkan berlakunya keadaan penyahjerapan akibat tarikan sesama molekul dan menyebabkan peningkatan pada tapak aktif permukaan. Peningkatan jumlah ion klorida dan bromida dalam medium VMNI turut meningkatkan lagi proses kakisan pada permukaan keluli. Namun julat peningkatan kadar kakisan yang diperoleh akibat penggunaan kepekatan amonium kuaterner yang lebih tinggi ini masih boleh diterima (memuaskan) bagi keadaan biokakisan persekitaran anaerobik yang melibatkan kehadiran SRB (Ahmad 2006). Kehadiran amonium kuaterner juga boleh menyebabkan penurunan kepekatan $\mathrm{H}_{2} \mathrm{~S}$ dalam medium ujian. Keadaan ini boleh berlaku melalui perencatan pertumbuhan SRB. Seterusnya, tindak balas metabolisme SRB melalui penurunan sulfat serta lain-lain ikatan sulfur seperti sulfit dan tiosulfat kepada ion-ion sulfida dapat diminimumkan

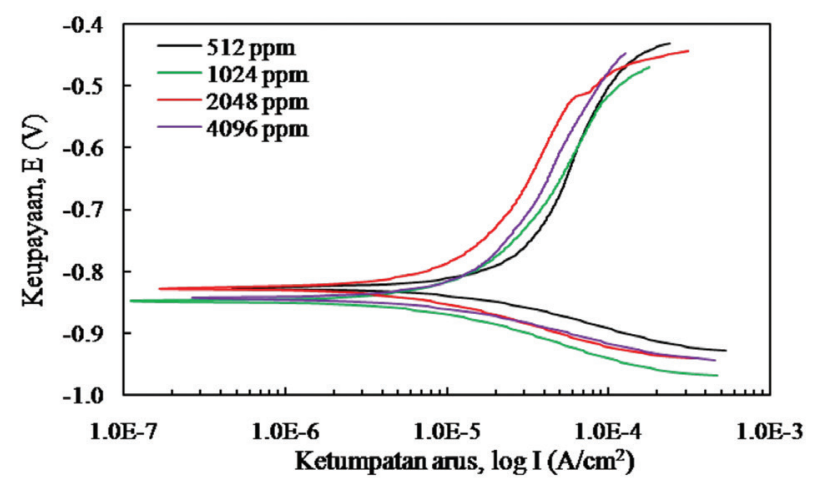

RAJAH 4. Plot PED bagi keluli karbon dengan kehadiran SRB pada kepekatan TMB yang berbeza

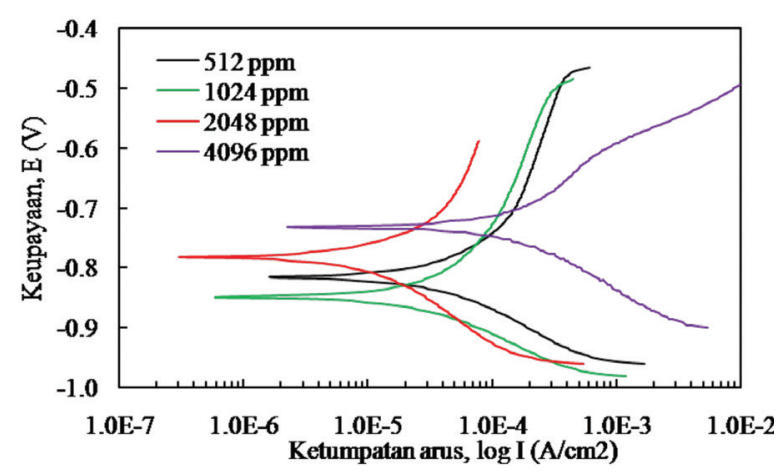

RAJAH 5. Plot PED bagi keluli karbon dengan kehadiran SRB pada kepekatan BTN yang berbeza 


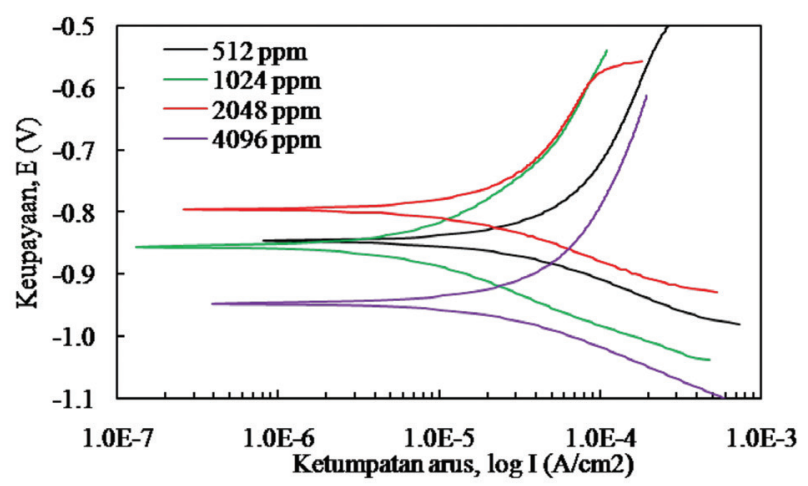

RAJAH 6. Plot PED bagi keluli karbon dengan kehadiran SRB pada kepekatan BKC yang berbeza

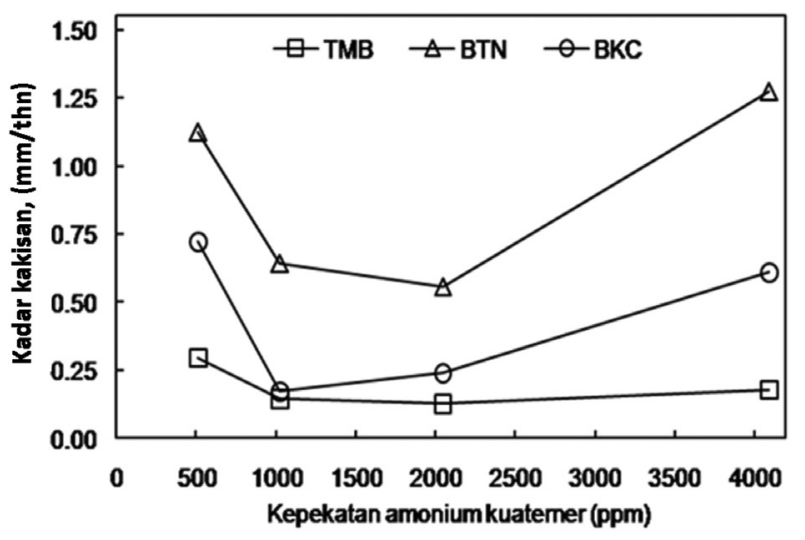

RAJAH 7. Kadar kakisan keluli karbon dengan penggunaan kepekatan amonium kuaternari yang berbeza dalam medium VMNI yang mengandungi SRB setelah tempoh inkubasi 7 hari

(Sass et al. 2009). Pengurangan ion sulfida secara tidak langsung menyekat tindak balas pembentukan $\mathrm{H}_{2} \mathrm{~S}$ yang boleh menjejaskan permukaan keluli karbon.

Keadaan ini dapat diperhatikan melalui analisis morfologi permukaan biofilem pada Rajah 8. Rajah 8(a) menunjukkan pertumbuhan aktif SRB pada permukaan keluli karbon serta pembentukan hasil metabolisme yang dikenali sebagai sebatian polimer luaran sel (EPS). Umumnya EPS terdiri daripada komponen polisakarida, lipid dan protein (Sheng et al. 2010). Pembentukan EPS dalam kuantiti yang besar membuktikan wujudnya pembentukan kepekatan $\mathrm{H}_{2} \mathrm{~S}$ yang tinggi bagi tempoh inkubasi 7 hari sampel berkenaan. Keadaan ini menyebabkan pembentukan kakisan yang tinggi bagi keluli karbon yang digunakan. Bagi Rajah 8(b) hingga Rajah 8(d), analisis morfologi ini menunjukkan jumlah pembentukan EPS adalah kurang berbanding Rajah 8(a). Keputusan ini menunjukkan ketiga-tiga sebatian TMB, BTN dan BKC berupaya mengurangkan jumlah pertumbuhan SRB dan seterusnya merencatkan pembentukan sebatian $\mathrm{H}_{2} \mathrm{~S}$ dengan terencatnya proses metabolisme semula jadi bakteria berkenaan.

Berdasarkan kedua-dua analisis PED dan SEM, dapat diperhatikan bahawa penggunaan sebatian TMB, BTN dan BKC berupaya mengawal kadar biokakisan pada permukaan keluli karbon melalui dua pembentukan mekanisme perlindungan. Perbezaan cas yang wujud pada permukaan keluli karbon akibat $\mathrm{pH}$, pengionan dan pemprotonan serta kehadiran ion-ion amonium kuaterner yang berbeza menyebabkan wujudnya tarikan daya elektrostatik antara kedua-dua cas berkenaan. Tarikan daya elektrostatik ini menyebabkan berlakunya proses penjerapan oleh molekul amonium kuaterner yang hadir di permukaan dengan molekul air yang mengalami penyahjerapan. Mekanisme ini dapat dinyatakan sebagai (1) (Idris et al. 2014);

$$
\mathrm{AK}_{\text {sol }}+x \mathrm{H}_{2} \mathrm{O}_{\text {ads }} \rightarrow \mathrm{AK}_{\text {ads }}+x \mathrm{H}_{2} \mathrm{O}_{\text {sol }}
$$

dengan $\mathrm{AK}_{\text {sol }}$ dan $\mathrm{AK}_{\text {ads }}$ masing-masing mewakili molekul amonium kuaterner dalam medium VMNI dan yang terjerap pada permukaan keluli. Manakala $\mathrm{H}_{2} \mathrm{O}_{\text {ads }}$ merujuk kepada molekul air yang terjerap pada permukaan keluli dan $x$ adalah bilangan molekul air yang diambil alih oleh molekul amonium kuaterner. Adalah diketahui bahawa mekanisme tindak balas kakisan yang berlaku pada permukaan keluli karbon disebabkan kehadiran bakteria SRB boleh dinyatakan melalui persamaan penyahkutuban katodik (Kakooei et al. 2012);

$$
\begin{aligned}
& \text { Tindak balas } \quad 4 \mathrm{Fe} \rightarrow 4 \mathrm{Fe}^{2+}+8 \mathrm{e}^{-} \\
& \text {anodik }
\end{aligned}
$$

$$
\text { Penguraian air } \quad 8 \mathrm{H}_{2} \mathrm{O} \rightarrow 8 \mathrm{H}^{+}+8 \mathrm{OH}^{-}
$$

$$
\begin{aligned}
& \text { Tindak balas } \quad 8 \mathrm{H}^{+}+8 \mathrm{e}^{-} \rightarrow 4 \mathrm{H}_{2} \\
& \text { katodik }
\end{aligned}
$$

$$
\begin{array}{ll}
\text { Pengoksidaan } & \mathrm{SO}_{4}^{2-}+4 \mathrm{H}_{2} \rightarrow \mathrm{H}_{2} \mathrm{~S}+2 \mathrm{H}_{2} \mathrm{O} \\
\text { hidrogen } & +2 \mathrm{OH}^{-}
\end{array}
$$

$$
\begin{array}{ll}
\text { Pemendakan } & \mathrm{Fe}^{2+}+\mathrm{H}_{2} \mathrm{~S} \rightarrow \mathrm{FeS}+2 \mathrm{H}^{+} \\
\text {Pemendakan } & 3 \mathrm{Fe}^{+}+6 \mathrm{OH}^{-} \rightarrow 3 \mathrm{Fe}(\mathrm{OH})_{2} \\
& \\
\text { Tindak balas } & 4 \mathrm{Fe}+\mathrm{SO}_{4}^{2-}+4 \mathrm{H}_{2} \mathrm{O} \rightarrow \mathrm{FeS} \\
\text { keseluruhan } & +3 \mathrm{Fe}(\mathrm{OH})_{2}+2 \mathrm{OH}_{-}
\end{array}
$$

Penjerapan molekul amonium kuaterner berupaya membentuk lapisan filem nipis bagi menghalang semua spesies kakisan seperti $\mathrm{H}_{2} \mathrm{~S}$, ion-ion halida dan air yang wujud dalam larutan daripada bertindak balas dengan permukaan keluli. Kehadiran kumpulan berfungsi benzil bagi sebatian BKC turut berupaya membantu meningkatkan proses jerapan antara ikatan dwigandaan karbon dan ferum melalui kehadiran $\pi$-elektron pada struktur aromatiknya. 

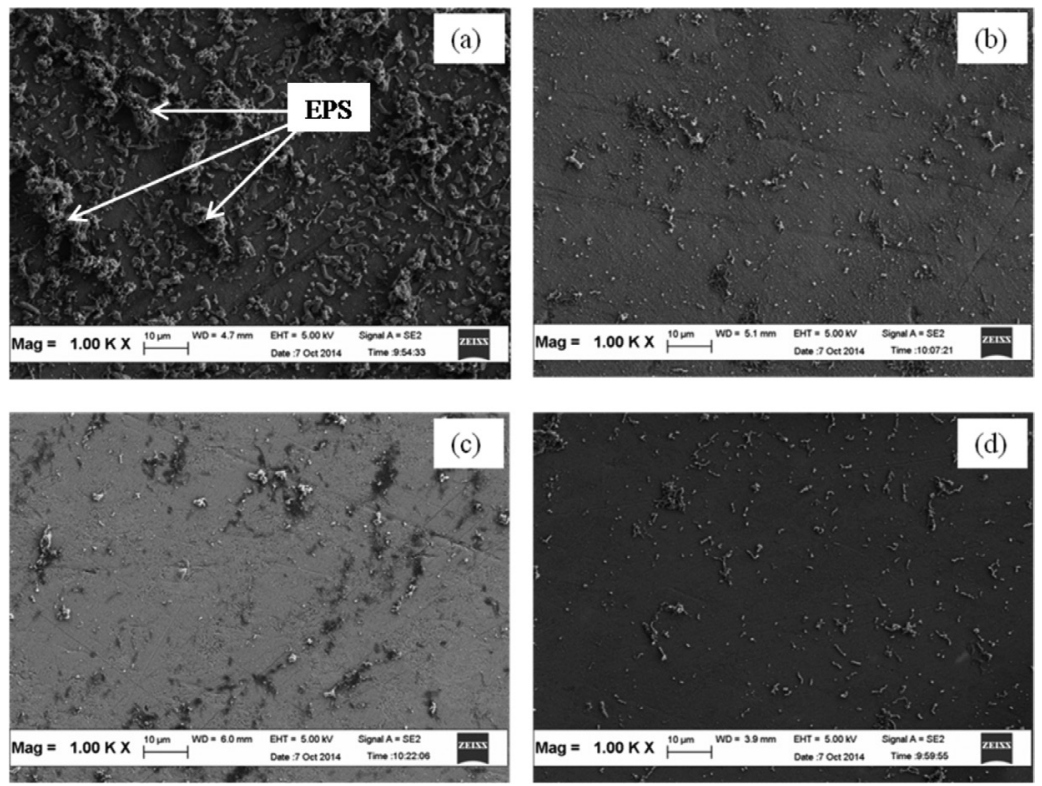

RAJAH 8. Analisis morfologi permukaan keluli karbon di dalam medium VMNI yang mengandungi SRB selepas inkubasi selama 7 hari (a) tanpa kuaternari amonium, (b) dengan kehadiran 4096 ppm TMB, (c) 4096 ppm BTN dan (d) 4096 ppm BKC

Bagi sebatian BTN, kehadiran kumpulan berfungsi O-H pada struktur ikatan kimianya turut berperanan dalam penjerapan pada permukaan keluli dan meningkatkan lagi keupayaan perencatan kakisan.

Selain penjerapan, ketiga-tiga sebatian amonium kuaterner juga mengawal kadar biokakisan keluli karbon melalui penyekatan pertumbuhan SRB. Keadaan ini berlaku melalui interaksi elektrostatik molekul amonium kuaterner pada permukaan membran luar SRB. Umumnya membran sel SRB adalah bercas negatif (Alabbas et al. 2012). Kewujudan kumpulan berfungsi hidrofilik dengan cas positif pada struktur amonium kuaterner menyebabkan berlakunya interaksi elektrostatik antara molekul ini dengan permukaan membran sel SRB yang boleh mengganggu proses metabolik pada sitoplasma sel dan seterusnya memusnahkan ketelapan membran sel SRB berkenaan (Badawi et al.2010). Keadaan ini menyebabkan pertumbuhan sel tidak dapat berlaku dan penghasilan ion sulfida daripada proses penurunan sulfat dapat dikawal.

Walau bagaimanapun, kajian ini masih pada peringkat awal dan kajian lanjutan bagi menilai keberkesanan sebatian amonium kuaterner ini melalui analisis biologi seperti ujian penyerapan cakera dan aktiviti biosidal masih perlu dijalankan. Pemencilan kepekatan amonium kuaterner juga boleh dijalankan bagi mendapatkan nilai kecekapan biosid yang lebih persis. Ujian kakisan seperti kehilangan berat untuk tempoh yang lebih lama juga perlu dijalankan termasuk penggunaan biosid ini di dalam persekitaran sebenar minyak mentah.

\section{KESIMPULAN}

Berdasarkan kajian ini, didapati bahawa kehadiran SRB telah menyebabkan biokakisan paling maksimum iaitu 8.91 $\mathrm{mm} /$ thn pada keluli karbon untuk tempoh inkubasi 7 hari di dalam medium VMNI. Namun penggunaan sebatian TMB, BTN dan BKC pada tempoh yang sama mendapati kadar kakisan masing-masing dapat dikurangkan kepada 0.13 , 0.56 dan $0.17 \mathrm{~mm} /$ thn pada penggunaan kepekatan 1024 ppm. Keberkesanan ketiga-tiga sebatian turut disahkan melalui analisis morfologi dengan kehadiran spesies SRB dan hasilan metabolisme yang rendah berbanding medium kawalan tanpa penggunaan amonium kuaterner. Pengawalan aktiviti SRB didapati berlaku secara mekanisme penjerapan dan interaksi elektrostatik yang memusnahkan struktur membran sel. Walau bagaimanapun, kajian lanjutan ketiga-tiga amonium kuaterner sebagai biosid kepada konsortium bakteria boleh diperincikan lagi dengan menggunakan kaedah penyerapan cakera dan analisis aktiviti biosidal.

\section{PENGHARGAAN}

Penulis merakamkan penghargaan kepada Kementerian Pengajian Tinggi, Malaysia dan Universiti Kebangsaan Malaysia atas sokongan dana melalui geran penyelidikan ERGS/1/2012/STGS05/UKM/02/2. Salah seorang penulis turut merakamkan penghargaan kepada Universiti Sains Malaysia atas kemudahan cuti belajar di bawah Rancangan Pendidikan Tinggi Kakitangan Akademik.

\section{RUJUKAN}

Abdullah, A., Yahaya, N., Md Noor, N. \& Mohd Rasol, R. 2014 Microbial corrosion of API 5L X-70 carbon steel by ATCC 7757 and consortium of sulfate-reducing bacteria. Journal of Chemistry 2014(1): 1-7.

Ahmad, Z. 2006. Principles of Corrosion Engineering and Corrosion Control. Oxford: Butterworth-Heinemann. 
Al-Jaroudi, S.S., Ul-Hamid,A. \& Al-Gahtani, M.M. 2011.Failure of cruide oil pipeline due to microbiologically induced corrosion. Corrosion Engineering, Science and Technology 46(4): 568-579.

Alabbas, F.M., Spear, J.R., Kakpovbia, A., Balhareth, N.M., Olson, D.L. \& Mishra, B. 2012. Bacterial attachment to metal substrate and its effects on microbiologically-influenced corrosion in transporting hydrocarbon pipeline. Journal of Pipeline Engineering 11(3): 63-72.

Badawi, A.M., Hegazy, M.A., El-Sawy, A.A., Ahmed, H.M. \& Kamel, W.M. 2010. Novel quaternary ammonium hydroxide cationic surfactants as corrosion inhibitors for carbon steel and as biocides for sulfate reducing bacteria (SRB). Materials Chemistry and Physics 124(1): 458-465.

Boivin, J. 1995. Oil industry biocides. Materials Performance 34(2): 65-68.

Davidova, I., Hicks, M.S., Fedorak, P.M. \& Suflita, J.M. 2001. The influence of nitrate on microbial processes in oil industry production waters. J.Ind. Microbiol. Biotechnol. 27(2): 8086.

Fathy, M., Badawi, A., Mazrouaa, A.M., Mansour, N.A., Ghazy, E.A. \& Elsabee, M.Z. 2013. Styrene N-vinylpyrrolidone metal-nanocomposites as antibacterial coatings against sulfate reducing bacteria. Materials Science and Engineering: C 33(7): 4063-4070.

Fink, J.K. 2013. Chapter 17 - Biocides. Dlm. Hydraulic Fracturing Chemicals and Fluids Technology, Fink, J.K. (pnyt.), Gulf Professional Publishing. hlm. 193-203.

Gardner, L.R. \& Stewart, P.S. 2002. Action of glutaraldehyde and nitrite against sulfate-reducing bacterial biofilms. J. Ind. Microbiol. Biotechnol. 29(6): 354-360.

Idris, M.N., Daud, A.R. \& Othman, N.K. 2014. Efficiency of benzyl dimethyl (2-hydroxyethyl) ammonium chloride as corrosion inhibitor in acetic acid. Australian Journal of Basic and Applied Sciences 8(15): 174-179.

Kakooei, S., Ismail, M.C. \& Ariwahjodi, B. 2012. Mechanism of microbiologically influenced corrosion: A review. World Applied Sciences Journal 17(4): 524-531.

Langumier, M., Sabot, R., Obame-Ndong, R., Jeannin, M., Sablé, S. \& Refait, P. 2009. Formation of Fe(III)-containing mackinawite from hydroxysulphate green rust by sulphate reducing bacteria. Corrosion Science 51(11): 26942702.

Mahat, N.A., Othman, N.K., Sahrani, F.K. \& Idris, M.N. 2015. Inhibition of consortium sulfate reducing bacteria from crude oil for carbon steel protection. Sains Malaysiana 44(11): 1587-1591.

Rusling, J.F. 1997. Molecular aspects of electron transfer at electrodes in micellar solutions. Colloids and Surfaces A: Physicochemical and Engineering Aspects 123-124(0): 8188.

Sass, H., Ramamoorthy, S., Yarwood, C., Langner, H., Schumann, P., Kroppenstedt, R.M., Spring, S. \& Rosenzweig, R.F. 2009. Desulfovibrio idahonensis sp. Nov., sulfate-reducing bacteria isolated from a metal (Loid)-contaminated freshwater sediment. International Journal of Systematic and Evolutionary Microbiology 59(9): 2208-2214.
Sheng, G-P., Yu, H-Q. \& Li, X-Y. 2010. Extracellular polymeric substances (EPS) of microbial aggregates in biological wastewater treatment systems: A review. Biotechnology Advances 28(6): 882-894.

Stipaničev, M., Turcu, F., Esnault, L., Schweitzer, E.W., Kilian, R. \& Basseguy, R. 2013. Corrosion behavior of carbon steel in presence of sulfate-reducing bacteria in seawater environment. Electrochimica Acta 113(0): 390-406.

Wen, J., Zhao, K., Gu, T. \& Raad, I.I. 2009. A green biocide enhancer for the treatment of sulfate-reducing bacteria (SRB) biofilms on carbon steel surfaces using glutaraldehyde. International Biodeterioration \& Biodegradation 63(8): 1102-1106

Xu, D., Wen, J., Fu, W., Gu, T. \& Raad, I. 2011a. D-amino acids for the enhancement of a binary biocide cocktail consisting of THPS and EDDS against an SRB biofilm. World Journal of Microbiology and Biotechnology 28(4): 1641-1646.

Xu, J., Wang, K., Sun, C., Wang, F., Li, X., Yang, J. \& Yu, C. $2011 \mathrm{~b}$. The effects of sulfate reducing bacteria on corrosion of carbon steel Q235 under simulated disbonded coating by using electrochemical impedance spectroscopy. Corrosion Science 53(4): 1554-1562.

Yemashova, N., Murygina, V., Zhukov, D., Zakharyantz, A., Gladchenko, M., Appanna, V. \& Kalyuzhnyi, S. 2007. Biodeterioration of crude oil and oil derived products: A review. Reviews in Environmental Science and Biol Technology 6(4): 315-337.

Mohd Nazri Idris*, Abdul Razak Daud, Nurakma Mahat \& Norinsan Kamil Othman

Pusat Pengajian Fizik Gunaan

Fakulti Sains dan Teknologi

Universiti Kebangsaan Malaysia

43600 Bangi, Selangor Darul Ehsan

Malaysia

Mohd Nazri Idris*

Pusat Pengajian Kejuruteraan Bahan dan Sumber Mineral

Universiti Sains Malaysia, Kampus Kejuruteraan

14300 Nibong Tebal, Pulau Pinang

Malaysia

Fathul Karim Sahrani

Pusat Pengajian Sains Sekitaran dan Sumber Alam

Fakulti Sains dan Teknologi

Universiti Kebangsaan Malaysia

43600 Bangi, Selangor Darul Ehsan

Malaysia

*Pengarang untuk surat-menyurat; email: nazriselama@gmail. com

Diserahkan: 5 Februari 2016

Diterima: 26 Mei 2016 